\title{
치과내원환자의 주관적 구강건강인식과 치과공포의 관련성 Relationship between Subjective Oral Health Recognition and Dental Fear in Dental Clinic Patients
}

\begin{abstract}
윤현서, 박지현**
인제대학교 의과대학 예방의학교실*, 영남대학교 보건대학원**

Hyun-Seo Yoon(dbsgustj76@hanmail.net)*, Ji-Hyun Park(pjhysb@naver.com)***

요약

본 연구는 부산·경남지역의 치과내원환자를 대상으로 주관적 구강건강인식과 상태 그리고, 치과진료 분 야에 치과공포수준을 파악하여 추후 치과진료 시 치과공포를 줄일 수 있는 방안을 마련하여, 구강건강의 향상과 더불어 삶의 질 향상에 기초자료로 개발하고자 한다. DFS의 전체 문항에서 100점 만점에 남자(44.9 점)보다 여자(53.1점)에서 공포감이 모두 높게 나타났다. 치료종류에 따른 공포수준은 임플란트 치료 치료 회피요인 $(\mathrm{p}=0.015)$, 교정치료 치료회피요인 $(\mathrm{p}=0.002)$, 생리적 반응요인 $(\mathrm{p}=0.009)$, 보철치료 치료회피요인 $(\mathrm{p}=0.014)$, 신경치료 치료회피요인 $(\mathrm{p}=0.005)$, 생리적 반응요인 $(\mathrm{p}=0.017)$, 치주치료 치료회피요인 $(\mathrm{p}=0.013)$, 생리적 반응요인 $(\mathrm{p}=0.004)$, 정기검진을 받지 않는 경우 치료회피요인 $(\mathrm{p}=0.027)$ 이 높았다. 구강증상에 대하 여 인지하고 있는 개수가 많을수록 치료회피요인 $(\mathrm{p}=0.001)$, 자극반응요인 $(\mathrm{p}=0.002)$, 생리적반응요인 $(\mathrm{p}=0.005)$ 로 높았다. 이상의 결과에서 치과공포를 줄이기 위해서는 정기검진과 예방적 처치를 위한 다양한 프로그램개발 및 구강보건교육을 실시해야 할 것이다.
\end{abstract}

- 중심어 : | 치과 공포감 | 주관적 구강건강 | 치과진료형태 |

\section{Abstract}

The purpose of this study is to develop basic data in improving quality of life along with the enhancement in oral health, by arranging a plan for being able to reduce dental fear given the dental treatment in the future by grasping the subjective oral health recognition \& status, and the dental fear level of the dental treatment field targeting patients of visiting dental clinics in Busan and Gyeongnam area. In the whole items of DFS, a sense of fear was higher in women than men. A factor of avoiding dental treatment stood at 1.72 points in men and 2.10 points $(\mathrm{p}<0.001)$ in women. A factor of response to stimulation stood at 2.75 points in men and 3.20 points $(\mathrm{p}=0.001)$ in women. A fear level according to dental kind was high in a factor of avoiding implant treatment $(\mathrm{p}=0.015)$, a factor of avoiding orthodontic treatment $(\mathrm{p}=0.002)$, physiological reaction( $\mathrm{p}=0.009)$, a factor of avoiding prosthesis treatment $(\mathrm{p}=0.014)$, a factor of avoiding pulpectomy treatment $(\mathrm{p}=0.005)$, a factor of physiological reaction $(\mathrm{p}=0.017)$, a factor of avoiding periodontal therapy $(\mathrm{p}=0.013)$, a factor of physiological reaction $(\mathrm{p}=0.004)$, and a factor of avoiding treatment given not receiving regular checkup(p=0.027). In the above results, to reduce dental fear, there will be a need of developing diverse programs and oral health eduction for regular checkup and preventive treatment.

- keyword : | Dental Fear I Oral Health Recognition I Dental Treatment |

접수번호 : \#120315-001

접수일자 : 2012년 03월 15일
심사완료일 : 2012년 05월 10일

교신저자 : 윤현서, e-mail : dbsgustj76@hanmail.net 


\section{I. 서 론}

최근 우리나라는 경제성장과 더불어 의학기술의 발 달로 인하여 질병 예방과 더불어 치료에 대한 다양한 방법들이 연구되어지고 있다[1]. 질병에 대한 치료의 결 과와 더불어 치료과정에서 환자가 느끼는 통증과 불안 감을 해소하기 위한 노력들을 다각도로 하고 있다. 특 히 구강건강에 대한 관심이 증대되면서 치과진료에 사 용되는 국소마취제를 비롯하여 다양한 장비와 재료들 이 발달함에 따라 치과진료 중 느끼게 되는 통증과 불 편감은 많이 해소되었으나, 여전히 치과진료에 대한 공 포심은 남아있으며, 이로 인하여 치과방문에 대한 부정 적인 생각으로 인하여 치료시기를 놓치게 되는 경우들 이 있다[2].

치과진료에 대한 공포감은 정도의 차이는 있으나 치 과치료 경험과 관계없이 남녀노소에서 나타나고 있다. 치과진료 기술이 많이 발달되었음에도 불구하고 1980 년대 조사결과 성인의 5-6\%가 치과진료에 대한 공포 심을 가지고 있는 것으로 나타났고, 이는 치과방문을 방해하는 여러 요소 중 가장 큰 비중을 차지하고 있다 [3][4].

치과에 대한 공포심을 유발하고, 영향을 미치는 요인 은 아주 다양하며, 이를 크게 직접경험, 간접경험(대리 경험), 개인적 특성 세 가지로 분류할 수 있다[5]. 첫 번 째로 직접경험은 치과진료 시 마취나, 치아삭제, 인상채 득 등에서 발생할 수 있는 통증이나, 불편감으로 본인 이 직접 경험을 바탕으로 형성되는 것을 의미한다. 두 번째로 간접경험(대리경험)은 치과치료 시 본인이외의 부모, 형제, 친구 등 주위사람들이 겪은 통증이나 불편 감을 간접적으로 경험하면서 느끼게 되는 것이다. 또한 사회공포증에 시달리고 있는 경우 수치심과 굴욕감의 공포로 인하여 진료를 회피하게 된다. 마지막으로 개인 적 특성은 불안의 취약성으로 인해 치과불안이 발생하 는 것이다.

Humphis 등[6]은 치과진료 시 불안감의 원인요소를 외상성 경험, 대리경험, 예비소인, 성격으로 분류하였으 며, 그 중 외상성 경험이 치과공포의 주원인이었다. 그 외에도 치과진료 중 예상치 못한 통증이나 불편감을 경
험하거나 국소마취주사의 경험에서 가장 뚜렷하다고 하였다.

Kleinknecht 등[7]이 개발한 Dental Fear Survey (DFS)는 치과공포의 요인을 다양한 항목으로 구성한 측정도구이다. DFS 하위척도는 진료회피요인, 생리적 반응요인, 치과진료자극 유발요인의 3 가지로 분류하였 다. 국내에서도 $\mathrm{DFS}$ 를 활용하여 치과공포와 관련된 연 구들이 이루어졌으며[8][9], 유럽 등[10][11]의 나라에서 도 치과공포관련 측정도구로 활용되고 있다.

McGrath C, Bedi R[12]은 치과공포와 구강 내 잔존 치수, 틀니 장착여부와의 관련성을 연구에서 잔존치아 수가 작고 틀니를 장착한 경우 공포심이 높았으며, 구 강건강과 삶의 질에 관한 연구에서도 치과공포가 높은 집단에서 삶의 질이 2 배 저하된다고 보고하여, 이는 치 과공포 수준이 구강상태에 영향을 미치는 것을 알 수 있었다.

최 등[13]의 연구에서 치료종류에 따른 공포감의 차 이를 조사한 결과 치아를 발치하거나, 충치치료를 경험 한 학생들이 교정치료나 불소도포, 치면열구전색을 경 험한 학생보다 치료에 대한 공포감이 높았다. 치료 중 에 국소마취와 치아삭제를 하게 되는 진료에서는 공포 감을 크게 느꼈으며, 장기간에 걸쳐 주기적으로 내원하 는 환자와 예방처치를 받은 환자는 공포심이 적었다. 현재 치과공포감에 대한 다양한 연구들이 이루어지고 있으나, 치료의 종류와 주관적 구강건강상태에 대한 공 포감에 관한 연구는 부족한 실정이다.

본 연구는 주관적 구강건강인식과 상태 및 치과진료 분야에 치과공포수준을 파악하여 추후 치과진료 시 치 과공포를 줄일 수 있는 방안을 마련하여, 구강건강의 향상과 더불어 삶의 질 향상에 기초자료로 개발하고자 한다.

\section{II. 연구 방법}

\section{1. 연구대상}

2009년 10월부터 2010년 3월말까지 부산. 경남지역 소 재의 치과 7곳에서 내원한 환자 중 치과공포에 대한 설 
문지 작성에 동의한 환자 340 명을 대상으로 자기기입 식 설문조사하였으며, 부적절한 설문지 29 부를 제외하 고 311 명을 대상으로 최종 분석하였다.

\section{2. 연구방법}

설문지의 질문 항목으로 일반적 특성을 파악하기 위 하여 성별, 연령, 결혼여부, 직업, 월 소득, 종교 등을 조 사하였으며, 구강보건 특성으로 교육수혜여부, 치료의 종류, 정기검진여부를 파악하였다. 치과치료의 공포에 대하여 Kleinknecht 등[7]에 의해 개발된 DFS를 국내 에서 최 등[13]의 연구결과를 바탕으로 이용하였다. $\mathrm{DFS}$ 총 20문항문항의 내용은 치료회피요인 8문항, 자 극반응요인 6 문항, 생리적반응요인 5 문항, 치과치료에 대한 전체적인 공포를 묻는 1 문항으로 세분화하여 구 성하였으며, 각 문항의 응답수준에 따라서 5 점 리커트 척도를 이용하여 매우 그렇다 5점, 그렇다 4점, 보통 3 점, 그렇지 않다 2점, 전혀 그렇지 않다 1점으로 산정하 여 점수가 높을수록 치과치료에 대한 공포감이 높은 것 으로 산정하였다. 또한 회수한 치과공포측정용 설문지 를 대상으로 신뢰도를 평가하여 Cronbach 의 신뢰도계 수를 산출한 결과 0.958 이었다

\section{3. 통계 분석.}

본 연구의 수집된 자료는 18.0 프로그램(SPSS Inc, Chicago, IL, USA)을 이용하여 분석하였다. 분석기법 으로 연구대상자의 일반적 특성과 구강보건 특성, DFS 응답분포를 파악하기 위하여 빈도와 백분율을 산출하 였으며, 일반적 특성, 치료종류, 건강인식, 구강건강상 태의 본인 인지에 따른 DFS 분포를 파악하기 위해서 t-test(검증), 그리고 One-way ANOVA(일원변량분석) 을 실시하였다.

\section{III. 연구결과}

\subsection{Dental fear survey(DFS)의 응답분포}

치과내원 환자의 공포감은 [표 1]과 같다. 전체 치과 공포감(DFS)를 100점 만점으로 환산하면남자 44.9점,
여자는 53.1점으로 여자에서 공포감이 높은 것으로 나 타났으며, 세부 요인 평균을 살펴보면 5점 만점에 치료 회피요인은 남자는 1.72 점이였고 여자는 2.10점으로 여 자에서 높게 나타났다 $(\mathrm{p}<0.001)$. 또한 자극반응요인에 서는 남자 2.75점, 여자는 3.20점으로 여자에서 높게 나 타났고 $(\mathrm{p}=0.001)$, 생리적 반응요인에서는 남자 1.98점, 여자는 2.35점으로 여자에서 높게 나타났다 $(\mathrm{p}<0.001)$. 세부요인 문항별로는 “주사바늘을 찌를 때 두려움을 느낀다”가 남자에서는 2.91점, 여자에서는 3.32점으로 모두에서 가장 높았으며 $(\mathrm{p}=0.006)$, 남자는 "치아삭제용 기구가 돌아가는 소리를 들었을 때 두려움을 느낀다” 2.83점, "치아가 삭제되고 있는 느낌을 받을 때 두려움 을 느낀다" 2.80점 순으로 나타났다. 여자는 “치아삭제 용 기구가 돌아가는 소리를 들을 때 두려움을 느낀다" 3.29점, "마취용 주사바늘을 볼 때 두려움을 느낀다" 3.21점 순으로 나타나 조금의 차이를 보였다[표 1].

\section{표 1. Dental fear survey(DFS)의 응답분포}

\begin{tabular}{|c|c|c|c|c|}
\hline 문항 내용 & 남자 & 여자 & 합계 & $p$ \\
\hline DFS합(100점 만점) & $\begin{array}{l}44.9 \pm \\
16.2\end{array}$ & $\begin{array}{l}53.1 \pm \\
16.0\end{array}$ & $\begin{array}{l}50.4 \pm \\
16.5\end{array}$ & $\langle 0.001$ \\
\hline 치료회피요인 & $\begin{array}{l}1.72 \pm \\
0.70\end{array}$ & $\begin{array}{l}2.10 \pm \\
0.75\end{array}$ & $\begin{array}{l}1.98 \pm \\
0.75\end{array}$ & $\langle 0.001$ \\
\hline $\begin{array}{l}\text { (1) 치과에 가는 것이 두려워서 치료 } \\
\text { 날짜를 미룬 적이 있다. }\end{array}$ & $\begin{array}{l}2.01 \pm \\
1.01\end{array}$ & $\begin{array}{l}2.49 \pm \\
1.18\end{array}$ & $\begin{array}{l}2.33 \pm \\
1.15\end{array}$ & $<0.001$ \\
\hline $\begin{array}{l}\text { (2) 치과에 가는 것이 두려워서 치료 } \\
\text { 약속을 취소한 적이 있다. }\end{array}$ & $\begin{array}{l}1.72 \pm \\
0.89\end{array}$ & $\begin{array}{l}2.10 \pm \\
0.97\end{array}$ & $\begin{array}{l}1.98 \pm \\
0.96\end{array}$ & 0.001 \\
\hline $\begin{array}{l}\text { (8) 치과 치료 약속을 정할 때면 두 } \\
\text { 려움을 느낀다. }\end{array}$ & $\begin{array}{l}1.94 \pm \\
0.98\end{array}$ & $\begin{array}{l}2.25 \pm \\
1.04\end{array}$ & $\begin{array}{l}2.15 \pm \\
1.03\end{array}$ & 0.012 \\
\hline $\begin{array}{l}\text { (9) 치과에 도착했을 때 두려움을 느 } \\
\text { 낀다. }\end{array}$ & $\begin{array}{l}1.88 \pm \\
0.93\end{array}$ & $\begin{array}{l}2.33 \pm \\
1.08\end{array}$ & $\begin{array}{l}2.19 \pm \\
1.06\end{array}$ & $\langle 0.001$ \\
\hline $\begin{array}{l}\text { (10) 대기실에서 치료를 기다릴 때 두 } \\
\text { 려움을 느낀다. }\end{array}$ & $\begin{array}{l}1.89 \pm \\
0.92\end{array}$ & $\begin{array}{l}2.42 \pm \\
1.11\end{array}$ & $\begin{array}{l}2.25 \pm \\
1.08\end{array}$ & $<0.001$ \\
\hline $\begin{array}{l}\text { (11) 치료의자에 앉아 치료를 기다릴 } \\
\text { 때 두려움을 느낀다. }\end{array}$ & $\begin{array}{l}2.12 \pm \\
1.09\end{array}$ & $\begin{array}{l}2.61 \pm \\
1.14\end{array}$ & $\begin{array}{l}2.45 \pm \\
1.14\end{array}$ & $<0.001$ \\
\hline $\begin{array}{l}\text { (12) 치과 특유의 냄새를 맡을 때 두 } \\
\text { 려움을 느낀다. }\end{array}$ & $\begin{array}{l}2.09 \pm \\
1.07\end{array}$ & $\begin{array}{l}2.49 \pm \\
1.15\end{array}$ & $\begin{array}{l}2.36 \pm \\
1.14\end{array}$ & 0.003 \\
\hline $\begin{array}{l}\text { (13) 치과위생사를 쳐다볼 때 두려움 } \\
\text { 을 느낀다. }\end{array}$ & $\begin{array}{l}1.95 \pm \\
1.03\end{array}$ & $\begin{array}{l}2.42 \pm \\
1.14\end{array}$ & $\begin{array}{l}2.27 \pm \\
1.13\end{array}$ & $<0.001$ \\
\hline 자극반응요인 & $\begin{array}{l}2.75 \pm \\
1.11\end{array}$ & $\begin{array}{l}3.20 \pm \\
1.01\end{array}$ & $\begin{array}{l}3.05 \pm \\
1.06\end{array}$ & 0.001 \\
\hline $\begin{array}{l}\text { (14) 마취용 주사바늘을 볼 때 두려움 } \\
\text { 을 느낀다. }\end{array}$ & $\begin{array}{l}2.80 \pm \\
1.29\end{array}$ & $\begin{array}{l}3.21 \pm \\
1.20\end{array}$ & $\begin{array}{l}3.08 \pm \\
1.24\end{array}$ & 0.006 \\
\hline $\begin{array}{l}\text { (15) 주사바늘을 찌를 때 두려움을 느 } \\
\text { 낀다. }\end{array}$ & $\begin{array}{l}2.91 \pm \\
1.28\end{array}$ & $\begin{array}{l}3.32 \pm \\
1.19\end{array}$ & $\begin{array}{l}3.19 \pm \\
1.23\end{array}$ & 0.006 \\
\hline $\begin{array}{l}\text { (16) 치아 삭제용 기구(드릴)를 보았 } \\
\text { 을 때 두려움을 느낀다. }\end{array}$ & $\begin{array}{l}2.83 \pm \\
1.27\end{array}$ & $\begin{array}{l}3.19 \pm \\
1.21\end{array}$ & $\begin{array}{l}3.07 \pm \\
1.24\end{array}$ & 0.018 \\
\hline
\end{tabular}




\begin{tabular}{|c|c|c|c|c|}
\hline $\begin{array}{l}\text { (17) 치아삭제용 기구가 돌아가는 소 } \\
\text { 리를 들을 때 두려뭄을 느낀다. }\end{array}$ & $\begin{array}{l}2.80 \pm \\
1.30\end{array}$ & $\begin{array}{l}3.29 \pm \\
1.19 \\
\end{array}$ & $\begin{array}{l}3.13 \pm \\
1.25\end{array}$ & 0.001 \\
\hline $\begin{array}{l}\text { (18) 치아가 삭제되고 있는 느낌을 받 } \\
\text { 을 때 두려움을 느낀다. }\end{array}$ & \begin{tabular}{|l|}
$2.80 \pm$ \\
1.27 \\
\end{tabular} & $\begin{array}{l}3.20 \pm \\
1.17\end{array}$ & $\begin{array}{l}3.07 \pm \\
1.21\end{array}$ & 0.006 \\
\hline $\begin{array}{l}\text { (19) 치석제거(스켈링)할 때 두려움을 } \\
\text { 느낀다. }\end{array}$ & $\begin{array}{l}2.37 \pm \\
1.11\end{array}$ & $\begin{array}{l}2.96 \pm \\
1.09\end{array}$ & $\begin{array}{l}2.77 \pm \\
1.13\end{array}$ & $\langle 0.001$ \\
\hline 생리적반응요인 & $\begin{array}{l}1.98 \pm \\
0.87\end{array}$ & $\begin{array}{l}2.35 \pm \\
0.86\end{array}$ & $\begin{array}{l}2.23 \pm \\
0.88\end{array}$ & $\langle 0.001$ \\
\hline $\begin{array}{l}\text { (3) 치과에 들어서면 근육이 긴장되 } \\
\text { 는 것 같다. }\end{array}$ & \begin{tabular}{|l|}
$2.18 \pm$ \\
1.07
\end{tabular} & $\begin{array}{l}2.73 \pm \\
1.13\end{array}$ & $\begin{array}{l}2.55 \pm \\
1.14\end{array}$ & $\langle 0.001$ \\
\hline $\begin{array}{l}\text { (4) 치과에 들어서면 호흡이 빨라지 } \\
\text { 는 것 같다. }\end{array}$ & $\begin{array}{l}1.96 \pm \\
0.95\end{array}$ & $\begin{array}{l}2.37 \pm \\
1.02\end{array}$ & $\begin{array}{l}2.24 \pm \\
1.02\end{array}$ & 0.001 \\
\hline $\begin{array}{l}\text { (5) 치과에 들어서면 진땀이 난 적이 } \\
\text { 있다. }\end{array}$ & \begin{tabular}{|l|}
$2.04 \pm$ \\
1.09
\end{tabular} & $\begin{array}{l}2.35 \pm \\
10.5\end{array}$ & $\begin{array}{l}2.25 \pm \\
1.07\end{array}$ & 0.015 \\
\hline $\begin{array}{l}\text { (6) 치과에 들어서면 구역질을 한 적 } \\
\text { 이 있다. }\end{array}$ & $\begin{array}{l}1.79 \pm \\
0.89\end{array}$ & $\begin{array}{l}1.92 \pm \\
0.84\end{array}$ & $\begin{array}{l}1.88 \pm \\
0.86\end{array}$ & 0.206 \\
\hline $\begin{array}{l}\text { (7) 치과에 들어서면 심장이 쿵쾅거 } \\
\text { 린다. }\end{array}$ & $\begin{array}{l}1.93 \pm \\
0.95\end{array}$ & $\begin{array}{l}2.39 \pm \\
1.05\end{array}$ & $\begin{array}{l}2.24 \pm \\
1.04\end{array}$ & $\langle 0.001$ \\
\hline $\begin{array}{l}\text { (20) 위 사항들을 고려할 때 치과치료 } \\
\text { 에 대한 전체적인 느낌은? }\end{array}$ & $\begin{array}{l}2.84 \pm \\
1.07\end{array}$ & $\begin{array}{l}3.00 \pm \\
0.91\end{array}$ & $\begin{array}{l}2.95 \pm \\
0.96\end{array}$ & 0.187 \\
\hline
\end{tabular}

\section{2 일반적 특성에 따른 DFS(치료회피, 자극 반} 응, 생리적 반응)요인

일반적 특성에 따른 치과공포 수준은 [표 2]와 같다. 연령에서는 40-49세에서 56.8 점 $(\mathrm{p}=0.05)$ 으로 가장 높았 고, 50세 이상 51.8점, 30-39세 50.8점, 20-29세 49.1점, 19세 이하 17.3점 순으로 나타났다. 세부적으로 치료회 피요인 2.27 점 $(\mathrm{p}=0.022)$, 자극반응요인 3.40 점 , 생리적 반응요인 2.48점 모두에서 가장 높게 나타났다.

결혼여부에서는 기혼이 55.4점, 미혼이 47.2점으로 기 혼 $(\mathrm{p}=<0.001)$ 에 높게 나타났으며, 세부적으로 치료회피 요인 2.23점 $(\mathrm{p}<0.001)$, 자극반응요인 3.27점 $(\mathrm{p}=0.002)$, 생리적반응요인 2.48점 $(\mathrm{p}<0.001)$ 으로 모두 높았다.

직업에서는 전문직에서 57.7점으로 가장 높았으며, 주부 56.6점, 자영업 54.6점, 회사원 50.3점, 학생 46.1점, 무직 또는 정년퇴임 42.3점 순으로 타나났다. 세부적으 로는 치료회피요인 2.31점 $(\mathrm{p}<0.001)$, 생리적반응요인 2.58 점 $(\mathrm{p}=0.001)$ 은 주부에서 높았고, 자극반응요인 3.76 점 $(\mathrm{p}<0.001)$ 으로 전문직에서 높았다. 월 소득에서는 401-500만원에서 56.0점으로 가장 높았으며, 500만원 이상 52.6점, 201-300만원 51.9점, 301-400만원 49.3점, 200만원 이하 48.2점 순으로 나타났다. 세부적으로는 치 료회피요인 2.28점, 자극반응요인 3.26점, 생리적반응요 인 2.50점으로 모두 높았다[표 2].
표 2. 일반적 특성에 따른 DFS(치료회피, 자극 반응, 생리 적 반응)

\begin{tabular}{|c|c|c|c|c|c|}
\hline 구분 & 항목 & $\begin{array}{c}\text { 치료회피 } \\
\text { 요인 }\end{array}$ & $\begin{array}{c}\text { 자극반응 } \\
\text { 요인 }\end{array}$ & $\begin{array}{c}\text { 생리적 } \\
\text { 반응요인 }\end{array}$ & 합계 \\
\hline \multirow[t]{6}{*}{ 연령군 } & 19세 이하 & $\begin{array}{c}1.83 \pm \\
0.89\end{array}$ & $\begin{array}{c}2.90 \pm \\
1.21\end{array}$ & $\begin{array}{c}2.04 \pm \\
1.00\end{array}$ & $\begin{array}{c}47.3 \pm \\
19.4\end{array}$ \\
\hline & $20-29$ & $\begin{array}{c}1.89 \pm \\
0.73\end{array}$ & $\begin{array}{c}3.01 \pm \\
1.13\end{array}$ & $\begin{array}{c}2.21 \pm \\
0.88\end{array}$ & $\begin{array}{c}49.1 \pm \\
16.5\end{array}$ \\
\hline & $30-39$ & $\begin{array}{c}2.01 \pm \\
0.70\end{array}$ & $\begin{array}{c}3.04 \pm \\
0.92\end{array}$ & $\begin{array}{c}2.26 \pm \\
0.85\end{array}$ & $\begin{array}{c}50.8 \pm \\
15.3\end{array}$ \\
\hline & $40-49$ & $\begin{array}{c}2.27 \pm \\
0.79\end{array}$ & $\begin{array}{c}3.40 \pm \\
0.84\end{array}$ & $\begin{array}{c}2.48 \pm \\
0.87\end{array}$ & $\begin{array}{c}56.8 \pm \\
15.8\end{array}$ \\
\hline & 50세 이상 & $\begin{array}{c}2.09 \pm \\
0.51\end{array}$ & $\begin{array}{c}3.07 \pm \\
0.93\end{array}$ & $\begin{array}{c}2.30 \pm \\
0.63\end{array}$ & $\begin{array}{c}51.8 \pm \\
12.0\end{array}$ \\
\hline & $\mathrm{p}$ & 0.022 & 0.199 & 0.156 & 0.050 \\
\hline \multirow[t]{3}{*}{ 결혼여부 } & 미혼 & $\begin{array}{c}1.81 \pm \\
0.76\end{array}$ & $\begin{array}{c}2.91 \pm \\
1.16\end{array}$ & $\begin{array}{c}2.07 \pm \\
0.88\end{array}$ & $\begin{array}{c}47.2 \pm \\
17.2\end{array}$ \\
\hline & 기혼 & $\begin{array}{c}2.23 \pm \\
0.68\end{array}$ & $\begin{array}{c}3.27 \pm \\
0.85\end{array}$ & $\begin{array}{c}2.48 \pm \\
0.82\end{array}$ & $\begin{array}{c}55.4 \pm \\
14.1\end{array}$ \\
\hline & $p$ & $<0.001$ & 0.002 & $\langle 0.001$ & $\langle 0.001$ \\
\hline \multirow[t]{5}{*}{ 학력 } & 중등재학,졸업 & $\begin{array}{c}1.73 \pm \\
0.76\end{array}$ & $\begin{array}{c}2.98 \pm \\
1.21\end{array}$ & $\begin{array}{c}1.93 \pm \\
0.75\end{array}$ & $\begin{array}{c}46.2 \pm \\
17.1\end{array}$ \\
\hline & 고등재학, 조업 & $\begin{array}{c}2.10 \pm \\
0.74\end{array}$ & $\begin{array}{c}3.05 \pm \\
1.04\end{array}$ & $\begin{array}{c}2.39 \pm \\
0.94\end{array}$ & $\begin{array}{c}52.2 \pm \\
16.8\end{array}$ \\
\hline & 대학재학 & $\begin{array}{c}1.70 \pm \\
0.65\end{array}$ & $\begin{array}{c}2.86 \pm \\
1.13\end{array}$ & $\begin{array}{c}2.01 \pm \\
0.82\end{array}$ & $\begin{array}{c}45.5 \pm \\
15.5\end{array}$ \\
\hline & 대학졸 이상 & $\begin{array}{c}2.09 \pm \\
0.77\end{array}$ & $\begin{array}{c}3.17 \pm \\
1.00\end{array}$ & $\begin{array}{c}2.32 \pm \\
0.86\end{array}$ & $\begin{array}{c}52.7 \pm \\
16.1\end{array}$ \\
\hline & $p$ & $<0.001$ & 0.281 & 0.008 & 0.009 \\
\hline \multirow[t]{7}{*}{ 직업 } & 학생 & $\begin{array}{c}1.74 \pm \\
0.74\end{array}$ & $\begin{array}{c}2.87 \pm \\
1.17\end{array}$ & $\begin{array}{c}2.03 \pm \\
0.90\end{array}$ & $\begin{array}{c}46.1 \pm \\
17.2\end{array}$ \\
\hline & 회사원 & $\begin{array}{c}2.00 \pm \\
0.76\end{array}$ & $\begin{array}{c}2.95 \pm \\
0.98\end{array}$ & $\begin{array}{c}2.27 \pm \\
0.86\end{array}$ & $\begin{array}{c}50.3 \pm \\
16.4\end{array}$ \\
\hline & 자영업 & $\begin{array}{c}2.15 \pm \\
0.75\end{array}$ & $\begin{array}{c}3.19 \pm \\
1.01\end{array}$ & $\begin{array}{c}2.51 \pm \\
0.94\end{array}$ & $\begin{array}{c}54.6 \pm \\
17.0\end{array}$ \\
\hline & 전문직 & $\begin{array}{c}2.22 \pm \\
0.72\end{array}$ & $\begin{array}{c}3.76 \pm \\
0.77\end{array}$ & $\begin{array}{c}2.34 \pm \\
0.91\end{array}$ & $\begin{array}{c}57.7 \pm \\
13.2\end{array}$ \\
\hline & 주부 & $\begin{array}{c}2.31 \pm \\
0.61\end{array}$ & $\begin{array}{c}3.30 \pm \\
0.89\end{array}$ & $\begin{array}{c}2.58 \pm \\
0.68\end{array}$ & $\begin{array}{c}56.6 \pm \\
13.4\end{array}$ \\
\hline & 무직 및정년퇴임 & $\begin{array}{c}1.70 \pm \\
0.77\end{array}$ & $\begin{array}{c}2.47 \pm \\
0.91\end{array}$ & $\begin{array}{c}1.89 \pm \\
0.84\end{array}$ & $\begin{array}{c}42.3 \pm \\
14.7\end{array}$ \\
\hline & $p$ & $\langle 0.001$ & $\langle 0.001$ & 0.001 & $\langle 0.001$ \\
\hline \multirow[t]{6}{*}{ 월소득 } & 200 이하 & $\begin{array}{c}1.87 \pm \\
0.77\end{array}$ & $\begin{array}{c}2.90 \pm \\
1.16\end{array}$ & $\begin{array}{c}2.17 \pm \\
0.93\end{array}$ & $\begin{array}{c}48.2 \pm \\
17.8\end{array}$ \\
\hline & $201-300$ & $\begin{array}{c}2.05 \pm \\
0.66\end{array}$ & $\begin{array}{c}3.18 \pm \\
0.95\end{array}$ & $\begin{array}{c}2.28 \pm \\
0.76\end{array}$ & $\begin{array}{c}51.9 \pm \\
13.9\end{array}$ \\
\hline & $301-400$ & $\begin{array}{c}1.90 \pm \\
0.73\end{array}$ & $\begin{array}{c}3.05 \pm \\
1.04\end{array}$ & $\begin{array}{c}2.15 \pm \\
0.85\end{array}$ & $\begin{array}{c}49.3 \pm \\
15.8\end{array}$ \\
\hline & $401-500$ & $\begin{array}{c}2.28 \pm \\
0.92\end{array}$ & $\begin{array}{c}3.26 \pm \\
1.12\end{array}$ & $\begin{array}{c}2.50 \pm \\
1.01\end{array}$ & $\begin{array}{c}56.0 \pm \\
19.2\end{array}$ \\
\hline & 500 이상 & $\begin{array}{c}2.13 \pm \\
0.63\end{array}$ & $\begin{array}{c}3.17 \pm \\
0.45\end{array}$ & $\begin{array}{c}2.35 \pm \\
0.93\end{array}$ & $\begin{array}{c}52.6 \pm \\
11.7\end{array}$ \\
\hline & $p$ & 0.053 & 0.292 & 0.307 & 0.131 \\
\hline
\end{tabular}


3.3 치료종류에 따른 DFS(치료회피, 자극 반응,

\section{생리적 반응)}

치료종류에 따른 치과공포수준은 [표 3]과 같다. 임플 란트치료를 받은 경우 56.8 점 $(\mathrm{p}=0.026)$ 으로 공포감이 높았으며 세부적으로는 치료회피요인( $\mathrm{p}=0.015)$, 자극 반응요인, 생리적 반응요인이 높았다. 보철치료를 받은 경우 53.5점(0.047) 공포감이 높았으며, 세부적으로 치 료회피요인 $(\mathrm{p}=0.014)$, 자극 반응요인, 생리적 반응요인 에서 높았다.

신경치료를 받은 경우 53.4점 $(\mathrm{p}=0.037)$ 으로 공포감이 높았으며, 세부적으로 치료회피요인 $(\mathrm{p}=0.005)$, 자극 반 응요인, 생리적 반응요인 $(\mathrm{p}=0.017)$ 이 높았다. 치주치료 를 받은 경우 51.7점 $(\mathrm{p}=0.010)$ 으로 공포감이 높았으며, 세부적으로 치료회피요인( $\mathrm{p}=0.013)$, 자극 반응요인, 생 리적 반응요인 $(\mathrm{p}=0.004)$ 이 높았다.

교정치료를 받지 않은 경우 52.5점 $(\mathrm{p}=0.032)$ 으로 공포 감이 높았으며, 세부적으로 치료회피요인 $(\mathrm{p}=0.002)$, 자 극 반응요인, 생리적 반응요인 $(\mathrm{p}=0.009)$ 이 높았다. 정기 검진을 받지 않는 경우 52.1점으로 공포감이 높았으며, 세부적으로 회피요인 $(\mathrm{p}=0.027)$, 자극 반응요인, 생리적 반응요인에서 높았다

따라서 임플란트치료, 보철치료, 신경치료, 치주치료 를 받은 경우 치과에 대한 공포감이 높은 반면, 교정치 료와 정기적 검진을 받는 경우에는 치과에 대한 공포감 이 낮은 것으로 나타났다[표 3].

표 3. 치료종류에 따른 DFS(치료회피, 자극 반응, 생리적 반응)

\begin{tabular}{|c|c|c|c|c|c|}
\hline \multicolumn{2}{|c|}{ 치료의 종류 } & $\begin{array}{c}\text { 치료회피 } \\
\text { 요인 }\end{array}$ & $\begin{array}{c}\text { 자극 } \\
\text { 반응요인 }\end{array}$ & $\begin{array}{c}\text { 생리적 } \\
\text { 반응요인 }\end{array}$ & 합계 \\
\hline 임플란트 & 예 & $\begin{array}{c}2.29 \pm \\
0.85\end{array}$ & $\begin{array}{c}3.31 \pm \\
1.13\end{array}$ & $\begin{array}{c}2.53 \pm \\
1.06\end{array}$ & $\begin{array}{c}56.8 \pm \\
19.1\end{array}$ \\
\hline & 아니오 & $\begin{array}{c}1.94 \pm \\
0.74\end{array}$ & $\begin{array}{c}3.02 \pm \\
1.05\end{array}$ & $\begin{array}{c}2.20 \pm \\
0.85\end{array}$ & $\begin{array}{c}49.7 \pm \\
16.1\end{array}$ \\
\hline & $p$ & 0.015 & 0.159 & 0.104 & 0.026 \\
\hline 교정치료 & 예 & $\begin{array}{c}1.85 \pm \\
0.77\end{array}$ & $\begin{array}{c}3.00 \pm \\
1.13\end{array}$ & $\begin{array}{c}2.11 \pm \\
0.94\end{array}$ & $\begin{array}{c}48.5 \pm \\
17.4\end{array}$ \\
\hline & 아니오 & $\begin{array}{c}2.11 \pm \\
0.72\end{array}$ & $\begin{array}{c}3.11 \pm \\
0.98\end{array}$ & $\begin{array}{c}2.37 \pm \\
0.78\end{array}$ & $\begin{array}{c}52.5 \pm \\
15.2\end{array}$ \\
\hline & $p$ & 0.002 & 0.397 & 0.009 & 0.032 \\
\hline 보철치료 & 예 & $\begin{array}{c}2.15 \pm \\
0.73\end{array}$ & $\begin{array}{c}3.17 \pm \\
1.01\end{array}$ & $\begin{array}{c}2.37 \pm \\
0.83\end{array}$ & $\begin{array}{c}53.5 \pm \\
15.9\end{array}$ \\
\hline
\end{tabular}

\begin{tabular}{|c|c|c|c|c|c|}
\hline & 아니오 & $\begin{array}{c}1.91 \pm \\
0.76\end{array}$ & $\begin{array}{c}3.01 \pm \\
1.08\end{array}$ & $\begin{array}{c}2.18 \pm \\
0.89\end{array}$ & $\begin{array}{c}49.3 \pm \\
16.6\end{array}$ \\
\hline & $p$ & 0.014 & 0.240 & 0.099 & 0.047 \\
\hline \multirow[t]{3}{*}{ 신경치료 } & 예 & $\begin{array}{c}2.16 \pm \\
0.74\end{array}$ & $\begin{array}{c}3.11 \pm \\
0.97\end{array}$ & $\begin{array}{c}2.42 \pm \\
0.84\end{array}$ & $\begin{array}{r}53.4 \pm \\
15.8\end{array}$ \\
\hline & 아니오 & $\begin{array}{c}1.90 \pm \\
0.75\end{array}$ & $\begin{array}{c}3.03 \pm \\
1.10\end{array}$ & $\begin{array}{c}2.16 \pm \\
0.88\end{array}$ & $\begin{array}{c}49.2 \pm \\
16.6\end{array}$ \\
\hline & $p$ & 0.005 & 0.503 & 0.017 & 0.037 \\
\hline \multirow[t]{3}{*}{ 충치치료 } & 예 & $\begin{array}{c}2.00 \pm \\
0.78\end{array}$ & $\begin{array}{c}3.07 \pm \\
1.09\end{array}$ & $\begin{array}{c}2.26 \pm \\
0.91\end{array}$ & $\begin{array}{c}50.8 \pm \\
17.1\end{array}$ \\
\hline & 아니오 & $\begin{array}{c}1.96 \pm \\
0.74\end{array}$ & $\begin{array}{c}3.04 \pm \\
1.05\end{array}$ & $\begin{array}{c}2.21 \pm \\
0.59\end{array}$ & $\begin{array}{c}50.2 \pm \\
16.1\end{array}$ \\
\hline & $p$ & 0.593 & 0.818 & 0.613 & 0.740 \\
\hline \multirow[t]{3}{*}{ 치주치료 } & 예 & $\begin{array}{c}2.03 \pm \\
0.74\end{array}$ & $\begin{array}{c}3.11 \pm \\
1.01\end{array}$ & $\begin{array}{c}2.31 \pm \\
0.86\end{array}$ & $\begin{array}{c}51.7 \pm \\
15.9\end{array}$ \\
\hline & 아니오 & $\begin{array}{c}1.78 \pm \\
0.79\end{array}$ & $\begin{array}{c}2.87 \pm \\
1.22\end{array}$ & $\begin{array}{c}1.97 \pm \\
0.89\end{array}$ & $\begin{array}{c}46.0 \pm \\
17.9\end{array}$ \\
\hline & $p$ & 0.013 & 0.139 & 0.004 & 0.010 \\
\hline \multirow[t]{3}{*}{$\begin{array}{c}\text { 정기검진여 } \\
\text { 부 }\end{array}$} & 예 & $\begin{array}{c}1.88 \pm \\
0.77\end{array}$ & $\begin{array}{c}2.98 \pm \\
1.14\end{array}$ & $\begin{array}{c}2.15 \pm \\
0.94\end{array}$ & $\begin{array}{c}48.8 \pm \\
17.4\end{array}$ \\
\hline & 아니오 & $\begin{array}{c}2.07 \pm \\
0.72 \\
\end{array}$ & $\begin{array}{c}3.12 \pm \\
0.98 \\
\end{array}$ & $\begin{array}{c}2.31 \pm \\
0.80 \\
\end{array}$ & $\begin{array}{c}52.1 \pm \\
15.4 \\
\end{array}$ \\
\hline & $p$ & 0.027 & 0.252 & 0.111 & 0.085 \\
\hline
\end{tabular}

\section{4 현재 본인이 인지하고 있는 구강증상에 따른} $\mathrm{DFS}$ (치료회피, 자극 반응, 생리적 반응)

현재 본인이 인지하고 있는 구강증상에 따른 치과공 포수준은 [표 4]와 같다. 구강건강상태의 불편감을 인지 하는 상태에서 7-9점이 57.4점으로 가장 높았고, 4-6점 52.0점, 0-3점이 47.0점 순으로 타나났으며, 세부적으로 치료회피요인 $(\mathrm{p}=0.001)$, 자극반응요인 $(\mathrm{p}=0.002)$, 생리적 반응요인 $(\mathrm{p}=0.005)$ 로 나타났다[표 4].

표 4. 현재 상태(인지하고)에 따른 DFS(치료회피, 자극 반 응, 생리적 반응)

\begin{tabular}{|c|c|c|c|c|}
\hline 인지상태 & 치료회피요인 & $\begin{array}{c}\text { 자극 } \\
\text { 반응요인 }\end{array}$ & $\begin{array}{c}\text { 생리적 } \\
\text { 반응요인 }\end{array}$ & 합계 \\
\hline 0-3점 & $1.84 \pm 0.74$ & $2.83 \pm 1.05$ & $2.08 \pm 0.86$ & $47.0 \pm 16.4$ \\
\hline 4-6점 & $2.02 \pm 0.74$ & $3.19 \pm 1.05$ & $2.30 \pm 0.89$ & $52.0 \pm 16.3$ \\
\hline 7-9점 & $2.32 \pm 0.73$ & $3.39 \pm 0.88$ & $2.56 \pm 0.83$ & $57.4 \pm 14.5$ \\
\hline$p$ & 0.001 & 0.002 & 0.005 & 0.001 \\
\hline
\end{tabular}

\section{5 구강상태 본인 인지 증상에 따른 DFS(치료회 피, 자극 반응, 생리적 반응)수준}

구강상태 본인 인지 증상에 따른 치과공포수준은 [표 
5]와 같다. 본인 인지 증상에서 치아가 흔들림이 58.4점 으로 가장 공포감이 높았으며, 충전물 탈락 치아 56.3점, 구치 54.7점, 상실치 53.0점, 충치와 깨진 치아 52.2점, 잇몸 피 51.5점 순으로 나타났다.

충치를 인지하고 있는 경우 52.2 점 $(\mathrm{p}=0.034)$ 으로 치과 에 대한 공포감이 높았으며, 세부적으로 치료회피요인 $(\mathrm{p}=0.049)$, 자극반응요인 $(\mathrm{p}=0.038)$, 생리적반응요인 $(\mathrm{p}=$ 0.049)로 높았다.

충전물 탈락 치아를 인지하는 경우 56.3 점 $(\mathrm{p}=<0.001)$ 으로 치과에 대한 공포감이 높았으며, 세부적으로 치료 회피요인 $(\mathrm{p}<0.001)$, 자극반응요인 $(\mathrm{p}=0.002)$, 생리적반응 요인 $(\mathrm{p}<0.001)$ 로 높았다.

치아 흔들림을 인지하는 경우 58.4점( $\mathrm{p}=<0.001)$ 으로 치과에 대한 공포감이 높았으며, 세부적으로 치료회피 요인 $(\mathrm{p}<0.001)$, 자극반응요인 $(\mathrm{p}=0.017)$, 생리적반응요인 $(\mathrm{p}<0.001)$ 로 높았다.

구취를 인지하는 경우 54.7 점 $(\mathrm{p}=0.003)$ 으로 치과에 대 한 공포감이 높았으며, 세부적으로 치료회피요인 $(\mathrm{p}=$ $0.002)$, 자극반응요인 $(\mathrm{p}=0.003)$, 생리적반응요인이 높았다.

잇몸통증을 인지하는 경우 52.2 점 $(\mathrm{p}=0.018)$ 으로 치과 에 대한 공포감이 높았으며, 세부적으로 치료회피요인 $(\mathrm{p}=0.020)$, 자극반응요인 $(\mathrm{p}=0.028)$, 생리적반응요인이 높았다.

상실치아를 인지하는 경우 53.0점으로 치과에 대한 공포감이 높았으며, 세부적으로 치료회피요인, 자극반 응요인, 생리적반응요인 $(\mathrm{p}=0.033)$ 이 높았으며, 치아통 증을 인지하는 경우 51.5점으로 치과에 대한 공포감이 높았으며, 세부적으로 치료회피요인, 자극반응요인 $(\mathrm{p}=0.006)$, 생리적반응요인이 높았으며, 잇몸출혈인 경 우 51.5점으로 치과에 대한 공포감이 높았으며, 세부적 으로 치료회피요인, 자극반응요인 $(\mathrm{p}=0.030)$, 생리적반 응요인이 높았다. 그러나 전체공포감에서는 유의하지 는 않았다[표 5].
표 5. 구강상태 본인 인지 증상에 따른 DFS(치료회피, 자극 반응, 생리적 반응)

\begin{tabular}{|c|c|c|c|c|c|}
\hline \multicolumn{2}{|c|}{ 구강건강인지여부 } & $\begin{array}{c}\text { 치료회피 } \\
\text { 요인 }\end{array}$ & $\begin{array}{c}\text { 자극반응 } \\
\text { 요인 }\end{array}$ & $\begin{array}{c}\text { 생리적 } \\
\text { 반응요인 }\end{array}$ & 합계 \\
\hline \multirow[t]{3}{*}{ 충치 } & 예 & $\begin{array}{c}2.05 \pm \\
0.71\end{array}$ & $\begin{array}{c}3.19 \pm \\
1.00\end{array}$ & $\begin{array}{c}2.32 \pm \\
0.84\end{array}$ & $\begin{array}{c}52.2 \pm \\
15.1\end{array}$ \\
\hline & 아니오 & $\begin{array}{c}1.88 \pm \\
0.80\end{array}$ & $\begin{array}{c}2.92 \pm \\
1.12\end{array}$ & $\begin{array}{c}2.13 \pm \\
0.91\end{array}$ & $\begin{array}{c}48.2 \pm \\
17.9 \\
\end{array}$ \\
\hline & $p$ & 0.049 & 0.038 & 0.049 & 0.034 \\
\hline \multirow[t]{3}{*}{$\begin{array}{c}\text { 충전물탈락 } \\
\text { 치아 }\end{array}$} & 예 & $\begin{array}{c}2.24 \pm \\
0.77\end{array}$ & $\begin{array}{c}3.35 \pm \\
1.03\end{array}$ & $\begin{array}{c}2.54 \pm \\
0.93\end{array}$ & $\begin{array}{c}56.3 \pm \\
16.5\end{array}$ \\
\hline & 아니오 & $\begin{array}{c}1.87 \pm \\
0.72\end{array}$ & $\begin{array}{c}2.93 \pm \\
1.05\end{array}$ & $\begin{array}{c}2.11 \pm \\
0.83\end{array}$ & $\begin{array}{c}48.1 \pm \\
15.9\end{array}$ \\
\hline & $p$ & $\langle 0.001$ & 0.002 & $\langle 0.001$ & $\langle 0.001$ \\
\hline \multirow[t]{3}{*}{ 깨진치아 } & 예 & $\begin{array}{c}2.08 \pm \\
0.70\end{array}$ & $\begin{array}{c}3.10 \pm \\
1.03\end{array}$ & $\begin{array}{c}2.35 \pm \\
0.85\end{array}$ & $\begin{array}{c}52.2 \pm \\
15.8\end{array}$ \\
\hline & 아니오 & $\begin{array}{c}1.94 \pm \\
0.77\end{array}$ & $\begin{array}{c}3.03 \pm \\
1.08\end{array}$ & $\begin{array}{c}2.19 \pm \\
0.89\end{array}$ & $\begin{array}{c}49.7 \pm \\
16.7\end{array}$ \\
\hline & $p$ & 0.142 & 0.613 & 0.140 & 0.235 \\
\hline \multirow[t]{3}{*}{ 잇몸 출혈 } & 예 & $\begin{array}{c}2.00 \pm \\
0.77\end{array}$ & $\begin{array}{c}3.14 \pm \\
1.05\end{array}$ & $\begin{array}{c}2.29 \pm \\
0.90\end{array}$ & $\begin{array}{c}51.5 \pm \\
16.5\end{array}$ \\
\hline & 아니오 & $\begin{array}{c}1.91 \pm \\
0.73\end{array}$ & $\begin{array}{c}2.86 \pm \\
1.06\end{array}$ & $\begin{array}{c}2.12 \pm \\
0.82\end{array}$ & $\begin{array}{c}48.1 \pm \\
16.4\end{array}$ \\
\hline & $p$ & 0.302 & 0.030 & 0.128 & 0.088 \\
\hline \multirow[t]{3}{*}{ 흔들림 } & 예 & $\begin{array}{c}2.35 \pm \\
0.77 \\
\end{array}$ & $\begin{array}{c}3.38 \pm \\
0.99\end{array}$ & $\begin{array}{c}2.70 \pm \\
0.82\end{array}$ & $\begin{array}{c}58.4 \pm \\
16.0 \\
\end{array}$ \\
\hline & 아니오 & $\begin{array}{c}1.90 \pm \\
0.73\end{array}$ & $\begin{array}{c}2.99 \pm \\
1.07\end{array}$ & $\begin{array}{c}2.14 \pm \\
0.86\end{array}$ & $\begin{array}{c}48.9 \pm \\
16.2\end{array}$ \\
\hline & $p$ & $\langle 0.001$ & 0.017 & $<0.001$ & $\langle 0.001$ \\
\hline \multirow[t]{3}{*}{ 구취 } & 예 & $\begin{array}{c}2.18 \pm \\
0.12\end{array}$ & $\begin{array}{c}3.33 \pm \\
1.05\end{array}$ & $\begin{array}{c}2.38 \pm \\
0.95\end{array}$ & $\begin{array}{c}54.7 \pm \\
17.6\end{array}$ \\
\hline & 아니오 & $\begin{array}{c}1.89 \pm \\
0.71\end{array}$ & $\begin{array}{c}2.94 \pm \\
1.05\end{array}$ & $\begin{array}{c}2.17 \pm \\
0.84\end{array}$ & $\begin{array}{c}48.6 \pm \\
15.7\end{array}$ \\
\hline & $\mathrm{p}$ & 0.002 & 0.003 & 0.077 & 0.003 \\
\hline \multirow[t]{3}{*}{ 상실치 } & 예 & $\begin{array}{c}2.09 \pm \\
0.70\end{array}$ & $\begin{array}{c}3.15 \pm \\
0.95\end{array}$ & $\begin{array}{c}2.39 \pm \\
0.88\end{array}$ & $\begin{array}{c}53.0 \pm \\
15.5\end{array}$ \\
\hline & 아니오 & $\begin{array}{c}1.92 \pm \\
0.77\end{array}$ & $\begin{array}{c}3.01 \pm \\
1.11\end{array}$ & $\begin{array}{c}2.16 \pm \\
0.87\end{array}$ & $\begin{array}{c}49.3 \pm \\
16.8\end{array}$ \\
\hline & $p$ & 0.066 & 0.270 & 0.033 & 0.072 \\
\hline \multirow[t]{3}{*}{ 치아통증 } & 예 & $\begin{array}{c}2.01 \pm \\
0.76\end{array}$ & $\begin{array}{c}3.15 \pm \\
1.08\end{array}$ & $\begin{array}{c}2.26 \pm \\
0.88\end{array}$ & $\begin{array}{c}51.5 \pm \\
16.5\end{array}$ \\
\hline & 아니오 & $\begin{array}{c}1.90 \pm \\
0.74\end{array}$ & $\begin{array}{c}2.78 \pm \\
0.99\end{array}$ & $\begin{array}{c}2.16 \pm \\
0.87\end{array}$ & $\begin{array}{c}47.7 \pm \\
16.2\end{array}$ \\
\hline & $p$ & 0.243 & 0.006 & 0.338 & 0.068 \\
\hline \multirow[t]{3}{*}{ 잇몸통증 } & 예 & $\begin{array}{c}2.06 \pm \\
0.78\end{array}$ & $\begin{array}{c}3.16 \pm \\
1.06\end{array}$ & $\begin{array}{c}2.31 \pm \\
0.89\end{array}$ & $\begin{array}{c}52.2 \pm \\
16.6\end{array}$ \\
\hline & 아니오 & $\begin{array}{c}1.85 \pm \\
0.71\end{array}$ & $\begin{array}{c}2.89 \pm \\
1.05 \\
\end{array}$ & $\begin{array}{c}2.12 \pm \\
0.86 \\
\end{array}$ & $\begin{array}{c}47.7 \pm \\
16.0 \\
\end{array}$ \\
\hline & $p$ & 0.020 & 0.028 & 0.054 & 0.018 \\
\hline
\end{tabular}




\section{IV. 결론 및 논의}

치과치료에서 불안과 공포감은 진료실에서 발생하는 문제 중 가장 빈도가 높은 문제이면서 환자, 치과의사, 치과위생사 모두에게 부정적 영향을 가져온다. 치과의 사는 해당 진료를 원활하게 수행할 수 없게 되고, 치과 위생사는 환자와의 관계형성을 통한 진료에 대한 동의 를 얻어내기가 힘들며, 환자역시도 불안감과 공포감으 로 인해 진료 시 정신적, 신체적으로 고통을 받게 되고 이로 인하여 결국은 내원을 포기하는 경우가 발생한다 [14]. 이렇듯 치과병·의원에서는 환자의 공포감을 줄이 기 위해 약물이나, 심리적 이완, 바이오 피드백등과 같 은 방법을 사용하고 있다. 그 중에서도 접근성이 높은 약물을 많이 선택하고 있으나 다양한 부작용이 발생할 수 있다[15]. 이에 환자의 공포감을 줄이기 위해서는 공 포감에 영향을 주는 요인을 파악하고 어떤 진료에 어느 정도의 공포감을 느끼는지를 파악함으로써 공포감을 줄여 원활한 진료를 진행할 수 있을 것이다.

본 연구에서는 치과에 내원한 환자를 대상으로 공포 감수준을 측정하기 위하여 널리 사용되어지고 있는 Dental Fear Survey Scale(DFS)를 이용하여 측정한 결 과 치과치료와 관련된 공포감의 평균점수는 50.4점으로 남자 44.9점, 여자 53.1점으로 나타나 이는 노르웨이[16] 44.6점, 미국[17] 40.6점, 덴마크[18] 39.1점 보다는 높았 으며, 터키[19]의 66.7점보다는 낮았다. 또한 총합이 60 점 이상 일 때 치과치료와 관련된 공포감이 높은 것으 로 판정[20]하였을 때 92명(29.6\%)에서 공포감이 높은 것으로 나타나 이는 김[21]의 연구에서 $30.9 \%$ 와 유사한 결과를 얻어 평균적으로 치과내원환자 10 명 중 3 명이 치과치료와 관련된 공포감을 크게 느낌으로 공포감을 줄이기 위한 다양한 치료방법을 찾아냄과 동시에 환자 의 마음을 안정시키기 위한 노력이 필요할 것이다.

치과공포의 요인별 수준은 치료자극요인 3.05점, 생 리적요인 2.23점, 치료회피요인 1.98점 순으로 나타났 다. 치료자극요인에서는 주사바늘을 찌를 때가 가장 높 았으며, 대부분 국소마취와 치아삭제에 관련된 항목이 높게 나왔고, 진료회피요인에서는 치료 의자에 앉아 치 료를 기다리는 두려움이 가장 큰 것으로 나타났고, 생
리적 요인에서는 치과에 들어서면 근육이 인장된다가 가장 높았다. 이는 이 등[15]의 연구에서 환자들이 느끼 는 치과 공포감의 주된 원인이 대기실의 기다림과 마 취, 치아삭제 소리 등으로 나타난 것과 일치하고, 박과 한[22], 최 등[13]의 연구 결과와 대부분이 일치하였다. 치과진료 시 공포감의 주된 원인이 되는 국소마취와 치 아삭제 시 발생하는 소음과 불편감을 줄이기 위하여 국 소마취 전 도포마취를 활용하거나, 치아삭제 시 발생하 는 소음을 줄이기 위하여 해드폰을 활용하여 환자가 원 하는 음악을 듣게 하는 등의 다양한 배려가 필요할 것 으로 생각된다.

일반적 특성에 따른 치과 공포감 정도 측정 결과 세 부요인 모두 여성에서 높았으며, 연령과, 학력, 직업, 소 득과는 관련성이 낮아 이는 정과 전[10], 최 등[13], 전 과 정[23]의 연구와 일치하였다.

치과치료의 종류에 따라서는 임플란트 $(\mathrm{p}=0.026)$ 보철 치료 $(\mathrm{p}=0.047)$, 신경치료 $(\mathrm{p}=0.037)$, 치주치료 $(\mathrm{p}=0.010)$ 는 치료를 받은 경우에 치과에 대한 공포감이 높았으며, 교정치료 $(\mathrm{p}=0.032)$ 의 경우에는 치료를 받지 않은 경우 에 공포감이 높은 것으로 나타나 이는 권과 최[24]의 연 구와 일치한 결과를 보였다. 또한 정기검진의 경우 검 진을 받지 않은 경우 공포감이 높았으나 통계적으로 유 의하지 않았으며, 이는 권과 최[24]의 연구에서 통계적 으로 차이를 보였던 것과는 다소 차이를 보였다.

현재의 구강건강상태가 나쁘다고 생각할수록 치료회 피요인 2.32점 $(\mathrm{p}=0.001)$, 자극반응요인 3.39점 $(\mathrm{p}=0.002)$, 생리적반응요인 2.56점 $(\mathrm{p}=0.005)$ 으로 공포감이 높은 것 으로 나타나 차[25]의 연구에서 자신의 치아상태가 문 제가 있다고 생각하는 경우 공포감이 크다와 일치함을 알 수 있었다. 정기적 검진과 예방처치 그리고 구강보 건교육을 통하여 구강건강상태가 좋아지게 되면 치과 에 대한 공포감도 줄어들 것으로 생각된다.

치과 공포감은 국소마취와 발치, 치아삭제 등을 경험 한 환자에서 높게 나타난 반면 예방처치나, 정기검진 그리고 정기적으로 내원하여 치료를 받는 교정치료환 자에게서는 낮게 나타났다. 이는 처음으로 환자가 어떤 치료의 경험을 갖게 되느냐에 따라서 공포감의 정도는 매우 달라진다고 할 수 있다. 따라서 치과를 처음 내원 
하였을 때 공포감을 높을 수 있는 처치는 뒤로 미루어 진료하는 것이 좋으며, 치료보다는 예방과 더불어 교육 에 대하여 관심을 높임으로서 환자의 공포감을 완화시 킬 수 있으리라 생각된다.

본 연구는 주관적 구강건강상태와 치료의 종류, 일반 적 특성에 따른 치과 공포감에 대하여 부산, 경남지의 치과7곳에서 내원하는 환자를 대상으로 연구하였기에 우리나라 전체를 대표할 수 없는 제한점을 가졌다. 그 러나 치과 공포감에 대한 관심이 높아지고 있고, 아직 연구들이 많이 이루어지지 않은 점에서 본 연구는 도움 이 되리라 생각이 된다. 추후 후속연구에서는 치과 공 포감을 완화시킬 수 있는 구체적인 방안을 제시할 수 있는 연구들이 이루어져야 하리라 사료된다.

\section{참 고 문 헌}

[1] K. C. Rhee, H. Y. Park, and D. I. Park, "The consumer information improvement for teen's oral health," Journal of Korean Home Management Association, Vol.23, No.2, pp.63-76, 2005.

[2] U. Berggren, "General and specific fears in referred and self-referred adult dental patients with extreme dental anxiety," Behav Res Ther, Vol.30, pp.395-401, 1992.

[3] M. L. Carah, E. N. Gale, and S. J. Illig, "Psychological stress reduction during dental procedure," J Dent Res, Vol.58, pp.1347-1351, 1979.

[4] P. A. Doerr, W. P. Lang, L. V. Nyquist, and D. L. Ronis, "Factors associated with dental anxiety," J Am Dent Asso, Vol.129, pp.1111-1119, 1998.

[5] I. Eli, "Antecedentals of dental anxiety:learned responses versus personality traits," Comm Dent Oral Epid, Vol.25, pp233-237, 1997.

[6] G. M. Humphris, T. Morrison, and S. J. E. Lindsay, "The modified dental anxiety scale: valiation and United Kingdom norms," Comm Dent Oral Epid, Vol.12, pp.143-150, 1995.

[7] R. A. Kleinknecht, "Factor analysis of the dental fear survey with cross-validation," J Am Dent Assoc, Vol.108, pp.59-61, 1984.

[8] 황혜림, 최하나, 조영식, “치과내원 환자의 불안취 약사고 경향 및 치과경험과 치과공포의 관련성”, 치위생과학회지, 제11권, 제1호, pp.15-21, 2011.

[9] 정명희, 전성희, "치과내원 환자의 이용형태 및 공 포와 구강악안면 통증”, 치위생과학회지, 제 9 권, 제3호, pp.361-367, 2009.

[10] J. Cesa, "Cross validation of a Brazilian version of the dental fear survey," Comm Dent Oral Epid, Vol.21, pp.148-150, 1993.

[11] Y. M. Daily, G. M. Humphris, and M. A. Lennon, "The use of dental anxiety questionnaires: a survey of group of UK dental practitioners," Br Dent J, Vol.190, pp.450-453, 2001.

[12] C. McGrath and R. Bedi, "The association between dental anxiety and oral health-reated quality of life in Britain," Comm Dent Oral Epid, Vol.32, pp.37-72, 2004.

[13] 최성숙, 김지영, 송근배, 이성국. "개인치과의원 내 원 청소년들의 치과치료 공포감에 대한 관련 요인 분석", 대한구강보건학회지, 제 28 권, 제 4 호, pp.495-503, 2004.

[14] 김성희, 백병주, 김재곤, “치과 방문시 어린이와 부모의 치과 불안의 상관관계”, 대한소아치과학 회지, 제32권, 제2호, pp.370-376, 2005.

[15] 이혜진, 전은숙, 이병호. "치과내원환자의 치과 치료시 공포감에 관한 연구”, 치위생과학회지, 제 7권, 제3호, pp.193-196, 2007.

[16] E. Skaret, M. Raadal, G. Kvale, and E. Berg, "Factors related to missed and cancelled dental appointments among adolescents in Norway," Eur J Oral Sci, Vol.108, No.3, pp.175-183, 2000. [17] M. Frazer, and S. Hampson, "Some personality 
factors related to dental anxiety and fear of pain," Br Dent J Vol.165, No.2, pp.436-439, 1988.

[18] R. Moore, U. Berggren, S. G. Carlsson, "Reliability and clinical usefulness of psychometric measures in a selfreferred population of odontophobics," Comm Dent Oral Epid, Vol.19, No.6, pp.347-351, 1991.

[19] K. Firat, E. P. Tunc, and V. Sar, "Dental anxiety amon adults in Turke," J Contemp Dent Pract, Vol.7, No.3, pp.75-82, 2006.

[20] E. Skaret, M. Raadal, E. Berg, and G. Kvale, "Dental anxiety among 18-yr-old in Norway. Prevalence and related factors," Eur J Oral Sic, Vol.31, No.4, pp.835-843, 1998.

[21] 김지영, 청소년의 치과치료와 관련된 공포감에 영 향을 미치는 요인에 관한 분석, 경북대학교 대 학원, 박사학위논문, pp.1-88, 2008.

[22] 박미정, 한경수, "치과외래환자에서 공포, 불안, 우 울 및 구강연면부 스트레스증상에 관한 연구”, 원광치의학, 제8권, 제3호, pp.129-144, 1998.

[23] S. H. Jun and M. H. Junh, "Relation between the degree of dental service on dental service provider and dental fear," J of Korean Acad of Hygiene Education, Vol.7, No.4, pp.535-551, 2007.

[24] 권수진, 최유진, "경남지역 청소년들의 치과진료 형태가 치과공포감에 미치는 영향”, 한국콘텐츠 학회지, 제10권, 제2호, pp.277-285, 2010.

[25] 차문호, 김진태, 손동수, 한세현, 김종철, 이상훈, “행동치과학", 의치학사, 1991.

\section{저 자 소 개}

윤 현 서(Hyun-Seo Yoon)

정회원

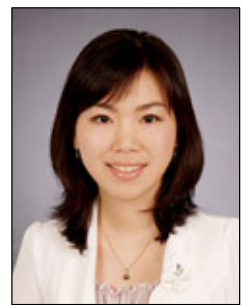

- 2008년 : 인제대학교 보건대학원 병원경영학 석사

- 2011년 : 인제대학교 대학원 보 건학과 박사

- 2012년 현재 : 인제대학교 의 과대학 연구원

<관심분야> : 보건학, 치위생학, 구강보건교육학

박 지 현(Ji-Hyun Park)

정회원

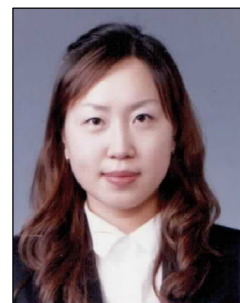

- 2010년 : 영남대학교 환경보건대 학원 보건학 석사

- 2011년 3월 현재 : 영남대학교 대학원 보건학과 박사과정

- 2010년 3월 현재 : 춘해보건대 학 치위생과 겸임교수

<관심분야> : 보건학, 치위생학, 구강미생물학 